\title{
KONSELING INDIVIDUAL DAN MEDIA LEAFLET MENINGKATKAN PENGETAHUAN IBU HAMIL TENTANG HEPATITIS B DALAM KEHAMILAN DI KELURAHAN TANJUNG AYUN SAKTI WILAYAH KERJA PUSKESMAS SEI JANG KOTA TANJUNGPINANG TAHUN 2017
}

\author{
Rahmadona $^{1}$, Dewi Mey Lestanti ${ }^{1}$, Respatiningrum ${ }^{1}$ \\ ${ }^{1}$ Program Studi Kebidanan, Poltekkes Kemenkes Tanjungpinang \\ Jl. Arif Rahman Hakim No.1 Tanjungpinang, Kepulauan Riau, Indonesia \\ Email: rdona81@gmail.com
}

\begin{abstract}
Abstrak
Penyakit hepatitis B pada kehamilan dapat menular pada janin. Di Tanjungpinang, terhitung sejak Maret tahun 2016 diidentifikasi 28 ibu hamil positif menderita Hepatitis B (HBsAg positif). Bayi yang tertular virus Hepatitis dari ibunya, 90\% mengidap Hepatitis Kronik selama hidup dan berpeluang menderita sirosis hepatis dan kanker hati apabila tidak ditangani. Pengetahuan ibu hamil tentang hepatitis B dalam kehamilan mutlak diperlukan untuk mencegah penularan dari ibu ke bayi. Penelitian ini bertujuan untuk mengetahui pengaruh pendidikan kesehatan dengan metode konseling individual dan media leafletterhadap peningkatan pengetahuan ibu hamil tentang hepatitis B dalam kehamilan. Penelitian pra eksperimen dengan rancangan one group pre test post test ini dilakukan di kelurahan Tanjung Ayun Sakti Wilayah Kerja Puskesmas Sei Jang terhadap 36 ibu hamil dengan menggunakan kuisioner dan data dikumpulkan sebanyak 2 kali dengan rentang waktu 1 minggu. Data selanjutnya diolah dan diuji statitistik dengan T-Tes dependent variables dengan derajat kemaknaan 95\%.Hasil dari penelitian ini diperoleh rata-rata pengetahuan ibu hamil sebelum diberi pendidikan kesehatan adalah 66.85 (SD 12.39) dan sesudah diberi pendidikan kesehatan 78.33 (SD 8.18) dengan peningkatan rata-rata pengetahuan sebesar 11.48. Hasil uji statistik T-test dependen variables menunjukkan nilai $\mathrm{p}=0.000$.
\end{abstract}

Kata Kunci : pendidikan kesehatan, pengetahuan, ibu hamil, hepatitis B

\section{PENDAHULUAN}

Penyakit hepatitis B merupakan masalah kesehatan masyarakat di dunia termasuk di Indonesia.Berdasarkan perspektif kesehatan masyarakat global, Infeksi hepatitis B kronik dapat berkembang menjadi sirosis hepatis dan kanker hati sebanyak $50 \%$ kasus di seluruh dunia dan $80 \%$ di daerah endemis tinggi virus hepatitis B (HBV) (Kemenkes RI, 2012; Lukmanto B, 2016; Odom J, Tita A dan Silverman N, 2016).

Indonesia adalah Negara dengan endemitas tinggi Hepatitis B, terbesar kedua di Negara South East Asian Region (SEAR) setelah Myanmar.Berdasarkan hasil riset kesehatan dasar (riskesdas) tahun 2013, diperkirakan 1 diantara 10 orang Indonesia telah terinfeksi hepatitis B atau $\mathrm{C}$, sehingga dari 28 juta penduduk Indonesia yang terinfeksi virus hepatitis B atau C, 14 juta diantaranya berpotensi menjadi kronis dan 1,4 juta dari yang kronis tersebut, berpotensi menderita kanker hati. Besaran masalah tersebut tentunya akan berdampak sangat besar terhadap masalah kesehatan masyarakat, produktifitas, umur harapan hidup dan dampak sosial ekonomi lainnya (Kemenkes RI, 2014)

Hepatitis B merupakan penyakit peradangan hati yang disebabkan infeksi virus hepatitis B (HBV) dan dapat bersifat akut maupun kronis dan termasuk penyakit hati yang paling berbahaya dibandingkan penyakit hati lainnya karena tidak 
menunjukkan gejala yang jelas. Penderita hepatitis B sering tidak menyadari telah terinfeksi dan tidak sadar sudah menularkan infeksi pada orang lain (Misnadiarly, 2007)

Pada kehamilan, risiko terinfeksi virus HBV sebenarnya sama denganwanita tidak hamil di usia yang sama dan dapat timbul di ketiga trimester kehamilan.Risiko yang diperoleh wanita hamil yang terinfeksi HBV antara laindapat mengalami abortus, persalinan prematur dan perdarahan. Ibu hamil yang terinfeksi HBV juga dapat menularkan infeksi secara vertikal ke janin yang dikandungnya saat persalinan maupun segera setelah persalinan.Bayi yang tertular HBV 90\% memiliki peluang mengidap hepatitis B kronik selama hidup dan berpeluang besar menderitasirosis hepatis dan kanker hati.(Kemenkes RI, 2012; Odom J, Tita A dan Silverman N, 2016 ).

Untuk wilayah kota Tanjungpinang, skrining hepatitis B pada ibu hamil yang dimulai sejak Maret 2016 telah menemukan28 orang ibu hamil terdeteksi positif HBsAg dari 1. $380 \mathrm{ibu}$ hamil yang di skrining (Dinkes Kota Tanjungpinang, 2017). Data tersebut dikumpulkan dari 7 puskesmas yang ada di kota Tanjungpinangdan Puskesmas Sei Jang melaporkan jumlah kasus terbanyak yaitu 9 orang ibu hamil $(32,14 \%)$. Lebih daripada itu, masih sedikit ibu hamil menjalani pemeriksaan atau skrining hepatitis B dibanding jumlah sasaran ibu hamil, dan lebih sedikit pula dari yang positif Hepatitis B mendapatkan pengobatan (Dinkes Kota Tanjungpinang, 2017).

$\begin{array}{lcr}\text { Kondisi } & \text { tersebut } & \begin{array}{c}\text { cukup } \\ \text { mengkhawatirkan }\end{array} \\ \text { mengingat } & \text { tingginya } \\ \text { risiko penularan dari ibu yang positif }\end{array}$

HBsAg ke janin dan bayi yang dilahirkan akan menjadi karier HBV seumur hidupnya. Ibu hamil positif HBsAg juga berpotensi menularkan infeksi pada anggota keluarga lain terutama anak-anak dan juga pada petugas kesehatan yang menolong proses persalinan (Radji, 2015).

Dari survey pendahuluan di wilayah Puskesmas Sei Jang, skrining tersebut hanya dilakukan pada ibu hamil yang melakukan kunjungan ANC ke Puskesmas, tidak seperti halnya skrining HIV yang dilakukan hingga ke wilayah pemukiman penduduk. Hal inimembuka kemungkinan jumlah ibu yang terinfeksi HBV jauh lebih besar dari yang terdata atau menunjukkan fenomena gunung es (Kemenkes RI, 2014)

Survey pendahuluan juga peneliti lakukan terhadap beberapa ibu hamil baik yang datang ke Puskesmas maupun yang berada di wilayah kerja puskesmas, dan sebagian besar tidak mengetahui tentang hepatitis B dalam kehamilan dan bahwa mereka harus menjalani skrining $\mathrm{HBsAg}$ dalam kehamilan.Pengetahuan mereka hanya sebatas pemeriksaan darah di puskesmas untuk deteksi HIV dan Penyakit Menular Seksual lainnya.

Peningkatan pengetahuan ibu hamil tentang skrining HBsAg dirasa perlu untuk membentuk sikap dan perilaku positif terhadap pencegahan penularan hepatitis dari ibu ke janin dan mencegah komplikasi yang timbul dari hepatitis B kronis.

\section{METODOLOGI}

Penelitian ini menggunakan desain pra eksperimen dengan rancangan one group pre - test post test yang bertujuan untuk mengetahui pengaruh pendidikan kesehatan dengan metode konseling individual dan media leaflet terhadap 
peningkatan pengetahuan ibu hamil tentang hepatitis B dalam kehamilan.

Pengumpulan data dilakukan pada bolan Juli - Oktober 2017 di kelurahan Tanjung Ayun Sakti wilayah kerja Puskesmas Sei Jang Kota Tanjungpinang. dengan jumlah ibu hamil 36 orang berdasarkan data terakhir bulan Agustus 2017. Dengan pertimbangan jumlah dan keterjangkauan pengambilan data penelitian secara individual, penelitian ini menggunakan seluruh populasi untuk dijadikan sampel (total sampling) yaitu sejumlah 36 orang.

Instrumen yang digunakan adalah kuisioner pernyataan tertutup untuk direspon oleh responden. Teknik pengumpulan data dilakukan sebanyak dua kali dalam bentuk tes sebelum perlakuan (pre test) dan setelah perlakuan (post test) yang dilakukan 1minggu setelah pre test.

Dipilih waktu 1 minggu untuk mengukur pengetahuan ibu hamil dengan mempertimbangkan bahwa pada masa itu sudah terjadi retensi informasi, dengan demikian pengetahuan yang terukur pada masa itu diperkirakan sudah tersimpan dalam memori jangka panjang subyek. Jika waktu pengulangan post test terlalu pendek kemungkinan subyek masih ingat pertanyaan-pertanyaan waktu pre test, sementara jika selang waktunya terlalu panjang kemungkinan akan terjadi perubahan pada variabel yang diteliti (Notoatmodjo, 2011).

Data yang terkumpul diolah dan dilakukan uji statistic menggunakan T-Test Dependent Variables dengan derajat kemaknaan $95 \%$.

\section{HASIL}

Data hasil penelitian didapatkan setelah mendatangi 36 subyek penelitian yang berada di Kelurahan Tanjung Ayun
Sakti sebanyak 2 kali yaitu pada saat pretest yang dilanjutkan dengan pemberian konseling individual mengenai Hepatitis B dalam kehamilan dan satu minggu kemudian untuk melakukan post test. Setelah data diolah dan dianalisis secara univarian dan bivariat diperoleh hasil sebagai berikut :

Tabel 1. Distribusi Peningkatan Pengetahuan Ibu Hamil Sebelum dan Sesudah Diberi Pendidikan Kesehatan

\begin{tabular}{lcccc}
\hline \multicolumn{1}{c}{ Variabel } & Mean & SD & $\begin{array}{c}\text { Beda } \\
\text { Mean }\end{array}$ & N \\
\hline $\begin{array}{l}\text { Pengetahuan } \\
\text { sebelum } \\
\text { diberikan } \\
\text { pendidikan } \\
\text { kesehatan }\end{array}$ & 66.85 & 12.39 & & \\
$\begin{array}{l}\text { Pengetahuan } \\
\text { setelah diberikan } \\
\text { pendidikan } \\
\text { kesehatan }\end{array}$ & 78.33 & 8.18 & & \\
\hline
\end{tabular}

Berdasarkan data pada tabel 1 di atas, terjadi peningkatan pengetahuan 36 orang ibu hamil yang diteliti sebelum dan sesudah diberikan pendidikan kesehatan tentang hepatitis B dalam kehamilan dari awalnya rata-rata skor pengetahuan 66.85 menjadi 78.33 dengan beda rata-rata mean sebesar 11.48 .

Tabel 2. Pengaruh Pendidikan Kesehatan Dengan Metode Konseling Individual dan Media Leaflet Terhadap Peningkatan Pengetahuan Ibu Hamil Tentang Hepatitis B Dalam Kehamilan

\begin{tabular}{|c|c|c|c|c|c|}
\hline Variabel & Mean & $\begin{array}{l}\text { Beda } \\
\text { Mean }\end{array}$ & SD & $\begin{array}{c}\mathrm{p} \\
\text { value }\end{array}$ & $\mathbf{N}$ \\
\hline $\begin{array}{l}\text { Pengetahuan } \\
\text { sebelum } \\
\text { diberikan } \\
\text { pendidikan } \\
\text { kesehatan }\end{array}$ & 66.85 & 11.48 & 10.02 & 0.000 & 36 \\
\hline $\begin{array}{l}\text { Pengetahuan } \\
\text { setelah }\end{array}$ & 78.33 & & & & \\
\hline
\end{tabular}


diberikan

pendidikan

kesehatan

Hasil uji statistik dengan menggunakan uji $\mathrm{t}$ berpasangan (paired samples $t$ test) seperti yang terlihat pada tabel 2 di atas, dapat dijelaskan bahwa selain ada peningkatan rata-rata pengetahuan ibu hamil sebelum diberi pendidikan kesehatan dari rata-rata skor pengetahuan 66.85 menjadi 78.33 dengan beda skor rata-rata sebesar 11.48, juga dapat diperoleh nilai $\mathrm{p} \mathrm{(} p$ value) yaitu 0.000. Dengan demikian dapat disimpulkan bahwa ada pengaruh signifikan antara pendidikan kesehatan dengan peningkatan pengetahuan ibu hamil tentang hepatitis $\mathrm{B}$ dalam kehamilan.

\section{PEMBAHASAN}

Hasil penelitian pengaruh pendidikan kesehatan dengan metode konseling individual dan media leaflet terhadap peningkatan pengetahuan ibu hamil tentang hepatitis B dalam kehamilan menunjukkan ada pengaruh signifikan ( $p$ value $=0.000$ ) antara kedua variabel tersebut. Peningkatan pengetahuan juga terlihat dari rata-rata skor pengetahuan ibu hamil sebelum diberi pendidikan kesehatan (pre test) adalah 66.85 menjadi 78.33 setelah diberi pendidikan kesehatan dengan beda nilai mean sebesar 11.48.

Hal ini sejalan dengan penelitian Wulan (2015) yang membuktikan ada pengaruh signifikan antara pendidikan kesehatan terhadap tingkat pengetahuan remaja tentang narkoba di Medan dengan nilai $\mathrm{p}=0.001$. Hal yang sama juga dibuktikan dari penelitian Sibagariang (2013) yang meneliti pengaruh pendidikan kesehatan tentang pencegahan diare terhadap pengetahuan dan sikap ibu bayi dengan nilai $\mathrm{p}=0.000$.

Pengetahuan menurut Notoatmodjo (2010) adalah hasil tahu dan ini terjadi setelah seseorang melakukan penginderaan terhadap suatu objek tertentu. Penginderaan terjadi melalui panca indera manusia yaitu indera penglihatan, pendengaran, penciuman, perasa, dan peraba. Sebagian besar pengetahuan manusia diperoleh memlaui mata dan telinga.

Pengetahuan merupakan domain penting dan merupakan faktor awal untuk terbentuknya perilaku seseorang dan ada hubungan yang positif antara kedua variabel tersebut. Pengetahuan dapat membentuk keyakinan tertentu sehingga seseorang dapat berperilaku sesuai keyakinan tersebut dan juga perilaku yang dilandasi oleh pengetahuan akan lebih melekat dan tahan lama dibandingkan perilaku yang tidak didasari oleh pengetahuan (Notoatmodjo, 2010).

Penelitian ini berdasarkan teori tersebut di atas, meneliti pengetahuan ibu hamil tentang hepatitis B dalam kehamilan sebagai faktor awal pembentukan kesadaran untuk mengembangkan sikap yang positif sehingga menghasilkan perilaku yang positif pula yang dalam hal ini adalah perilaku kewaspadaan terhadap risiko penularan hepatitis $\mathrm{B}$ dalam kehamilan antara ibu dan janin serta secara sadar mau memeriksakan diri atau melakukan skrining hepatis B di institusi pelayanan kesehatan atau Puskesmas yang menyediakan pelayanan skrining hepatitis B bagi ibu hamil.

Peningkatan pengetahuan juga tidak terlepas dari faktor yang mempengaruhinya baik dari internal diri seseorang meliputi taraf intelegensia berdasarkan latar belakang pendidikan, 
minat dan kondisi fisik, faktor eksternal mencakup dukungan keluarga, masyarakat, tenaga kesehatan dan sarana serta faktor pendekatan belajar yang dalam hal ini adalah pendidikan kesehatan (Notoatmodjo, 2011).

Bermaknanya pengaruh pendidikan kesehatan terhadap peningkatan pengetahuan dalam penelitian ini dimungkinkan dari latar belakang pendidikan formal ibu hamil yang mayoritas tamat SMA (69.4\%) dimana pada tingkatan ini diasumsikan taraf intelegensianya sudah cukup untuk merespon secara positif informasi yang diberikan melalui pendidikan kesehatan dan menerimanya dan mengolahnya menjadi suatu pengetahuan baru. Selain itu, kondisi fisik responden yang sedang hamil, dan pengetahuan tentang hepatitis B dalam kehamilan mungkin dirasakan sesuai dan penting untuk kehamilannya, bisa memicu minat responden untuk menambah pengetahuannya tentang hepatitis B dalam kehamilan yang bisa diperoleh salah satunya dari pendidikan kesehatan.

Faktor eksternal yang mempengaruhi peningkatan pengetahuan seseorang tidak terlepas dari adanya dukungan keluarga, masyarakat, tenaga kesehatan dan sarana penunjang. Dalam penelitian ini, dukungan terutama dari tenaga kesehatan berupa informasi tentang hepatitis B dalam kehamilan dan keharusan melakukan skrining hepatitis B dalam kehamilan dinilai masih kurang sejalan. Hal ini berdasarkan survey awal dan hasil penelitian yang diperoleh, mayoritas ibu hamil (91.7\%) mengaku tidak pernah mendapatkan informasi sebelumnya mengenai hepatitis B dalam kehamilan namun demikian, umumnya
(94.4 \%) mengatakan sudah pernah diskrining di Puskesmas.

Skrining Hepatitis B pada ibu hamil di Puskesmas sudah menjadi program pemerintah Kota Tanjungpinang sejak pertengahan tahun 2016 dan dilakukan pada setiap ibu hamil kapan saja selama kehamilan dan pelayanannya diintegrasikan dalam pemeriksaan sampel darah bersamaan dengan pemeriksaan HIV, sifilis dan penyakit menular seksual lainnya (Kemenkes RI, 2015; Dinkes Kota Tanjungpinang, 2016). Saat dikonfirmasi mengenai hal ini, umumnya responden mengatakan bahwa sudah melakukan pemeriksaan darah di Puskesmas namun tidak mengetahui pemeriksaan tersebut salah satunya untuk skrining Hepatitis B dan juga tidak mendapatkan informasi yang lengkap tentang hepatitis B dalam kehamilan dan pentingnya melakukan skrining hepatitis B dalam kehamilan dari tenaga kesehatan.

Faktor pendekatan belajar juga berperan dalam peningkatan pengetahuan seseorang. Dalam penelitian ini, peningkatan pengetahuan ibu hamil tentang hepatitis B dalam kehamilan dilakukan dengan memberikan pendidikan kesehatan. Menurut Notoatmodjo (2010), pendidikan kesehatan merupakan penerapan konsep pendidikan dalam bidang kesehatan. Konsep dasar pendidikan itu sendiri merupakan suatu proses belajar sehingga pendidikan kesehatan dapat diartikan sebagai proses belajar pada diri individu, kelompok, atau masyarakat dari yang tidak tahu menjadi tahu, dari yang tidak mampu mengatasi masalah kesehatan menjadi mampu mengatasi masalah kesehatan.

Lebih lanjut lagi, menurut Green, et.al (2000) dalam Simbolon (2008) Pendidikan kesehatan merupakan 
kombinasi pengalaman belajar yang dirancang demi memudahkan penyesuaian sukarela dari perilaku yang kondusif bagi kesehatan. Pemilihan metode yang sesuai dan penggunaan media pendidikan kesehatan turut membantu memudahkan penerimaan informasi yang disampaikan melalui pendidikan kesehatan (Notoatmodjo, 2010)

Hal tersebut di atas tercermin dari hasil penelitian ini dimana rata-rata skor pengetahuan ibu hamil tentang hepatitis B dalam kehamilan sebelum diberi pendidikan kesehatan adalah 66.85 dengan standar deviasi 12.39. Setelah diberi pendidikan kesehatan tentang segala hal yang perlu diketahui ibu hamil tentang hepatitis B dalam kehamilan, rata-rata skor pengetahuan ibu hamil meningkat menjadi 78.33, standar deviasi 8.18 dengan beda rata-rata (mean) sebesar 11.48.

Pendekatan metode pendidikan kesehatan dalam penelitian ini menggunakan konseling individual dengan pertimbangan jumlah responden yang bisa terjangkau seluruhnya dan tidak memungkinkannya mengumpulkan seluruh ibu hamil di satu tempat dan di satu waktu. Dengan pendekatan ini, kontak antara responden dan peneliti lebih intensif untuk mengatasi masalah responden sehingga responden dengan sukarela, berdasarkan kesadaran menerima informasi dan mengembangkannya menjadi suatu pengetahuan dan perilaku yang baru (Notoatmodjo, 2010).

Media yang digunakan dalam penelitian ini menggunakan leaflet sebagai alat bantu pendidikan kesehatan. Sesuai dengan pendapat Mubarak (2007) bahwa media pendidikan kesehatan pada hakekatnya adalah alat bantu pendidikan yang digunakan oleh pendidik untuk menyampaikan bahan pendidikan/pengajaran.

Tujuan penggunaan media menurut Notoatmodjo (2010) adalah untuk menimbulkan minat sasaran pendidikan kesehatan, mencapai sasaran lebih banyak, membantu mengatasi hambatan dalam pemahaman, dan membantu sasaran pendidikan kesehatan untuk melaksanakan pesan-pesan kesehatan.

Dengan penggunaan metode dan media pendidikan kesehatan yang benar dan baik, maka pesan, ide, gagasan dan informasi yang disampaikan oleh pemberi pendidikan kesehatan akan mudah diterima dan dapat dijadikan untuk sarana meningkatkan pengetahuan ibu hamil khususnya tentang hepatitis B dalam kehamilan. Hal tersebut terbukti dalam penelitian ini bahwa dengan memberikan pendidikan kesehatan menggunakan metode konseling individual dan media leaflet ternyata mampu meningkatkan pengetahuan ibu hamil tentang hepatitis $B$ dalam kehamilan dengan hasil uji statistik signifikan ( $\mathrm{p}$ value $=0.000$ ).

\section{KESIMPULAN}

Berdasarkan hasil penelitian yang telah dilaksanakan pada ibu hamil di Kelurahan Tanjung Ayun Sakti Wilayah Kerja Puskesmas Sei Jang diperoleh kesimpulanbahwa ada pengaruh signifikan antara pendidikan kesehatan dengan metode konseling individual dan media leaflet terhadap peningkatan pengetahuan ibu hamil tentang hepatitis B dalam kehamilan dengan nilai $\mathrm{p}=0.000$

\section{DAFTAR PUSTAKA}

Borgia G. et al. 2012. Hepatitis B in Pregnancy. World Journal of Gastroenterology. 2012 September 14. Vol 18.Issue 34. Pg.4677-4683 
Corwin, E.J. 2009. Buku Saku Ptofisiologi. Alih bahasa. Nike Budhi Subekti, dkk. Penerbit Buku Kedokteran. Jakarta.

Dahlan MS. 2009. Besar'Sampel dan Cara Pengambilan Sampel Dalam Penelitian Kedokteran dan Kesehatan Edisi 2. Salemba Medika. Jakarta.

Dahlan MS. 2009. Statistik Untuk Kedokteran dan Kesehatan Edisi 4. Salemba Medika. Jakarta.

Dharma, K. 2011. Metodogi Penelitian Keperawatan. Panduan Melaksanakan dan Menerapkan Hasil Penelitian.Trans Info Media. Jakarta.

Dinkes Kota Tanjungpinang.2016.Profil Kesehatan Kota Tanjungpinang Tahun 2015.Dinas Kesehatan Kota Tanjungpinang.Tanjungpinang.

Dinkes Prov. Kepri. 2016. Profil Kesehatan Provinsi Kepulauan Riau Tahun 2015. Dinas Kesehatan Provinsi Kepulauan Riau. Tanjungpinang.

Fajar I, dkk. 2009. Statistika Untuk Praktisi Kesehatan. Graha Ilmu. Yogyakarta.

Firda, Yani T. (2013) Panduan Klinis Kehamilan Dan Persalinan. DMedika (Anggota IKAPI). Yogyakarta.

Gunardi H, dkk. 2014. Current Prevalence of Hepatitis $b$ Infection Among Parturient Women in Jakarta, Indonesia. Acta Medica Indonesia. The Indonesian Journal of Internal Medicine. 2014 January.Vol 3 (1).Pg.3-9.

Hidayat, A. 2007.Metode Penelitian Kebidanan dan Teknik Analisis Data. Salemba Medika. Jakarta

Ho V and Ho W. 2012. Hepatitis in Pregnancy. Specific issues and consideration. Journal Antivirus and Antiretrovirus. Vol 4(3).Pg. 051-059.
Kemenkes RI. 2012. Pedoman Pengendalian Hepatitis Virus.Ditjen PP dan PL Kementerian Kesehatan RI. Jakarta

Kemenkes RI. 2013. Riset Kesehatan Dasar Tahun 2013. Badan Penelitian dan Pengembangan Kementerian Kesehatan RI. Jakarta.

Kemenkes RI. 2014. Situasi dan Analisis Hepatitis. Pusat Data dan Informasi Kementerian Kesehatan RI. Jakarta.

Kemenkes RI. 2015. Petunjuk Teknis Deteksi Dini Hepatitis B dan C Pada Kelompok Masyarakat Berisiko Tinggi. Ditjen PP dan PL Kementerian Kesehatan RI. Jakarta.

Kusmiyati, dkk. 2009.Perawatan Ibu Hamil (Asuhan Ibu Hamil). Fitramaya. Yogyakarta.

Lukmanto B, 2016. Hepatitis Pada Kehamilan. Diakses darihttp://www.budilukmanto.org/in dex.php/seputar-hepatitis/96hepatitisTanggal 14 April 2017

Misnadiarly. 2007. Beberapa faktor yang berhubungan dengan status kelengkapan imunisasi hepatitis B pada bayi di Puskesmas Lanjas Kabupeten Barito UtamaKalimantan Tengah. Medik Indonesia. Vol 4. Hal. 251-7

Nelson N, et.al. 2014. Prevention of Perinatal Hepattitis $B$ Virus Transmission. Journal of The Pediatric Infectious Diseases Society. 2014 May 22. Vol.3.Suppl.1.Pg 7-12.

Notes L. 2008. Penyakit Infeksi. Edisi keenam. Penerbit Erlangga. Jakarta.

Notoatmodjo, S. 2007. Promosi Kesehatan dan Ilmu Perilaku. Rineka Cipta. Jakarta.

Notoatmodjo, S. 2010a. Metodologi Penelitian Kesehatan. Rineka Cipta. Jakarta 
Notoatmodjo, S. 2010b. Pendidikan dan Perilaku Kesehatan. Rineka Cipta. Jakarta

Notoatmodjo, S. 2011. Ilmu Perilaku Kesehatan. Rineka Cipta. Jakarta.

Odom J, Tita A and Silverman N. 2016. Hespatitis $B$ in Pregnancy screening, treatment, and prevention of vertical transmission.American Journal of Obstetric and Gynecology. January 2016. Cited 2017 April 14.

Radji, M. 2015. Immunologi dan Virologi. Cetakan kedua. Penerbit PT. ISFI. Jakarta

Riyanto, A. 2011. Aplikasi Metode Penelitian Kesehatan. Nuha Medika. Yogyakarta.

Sahai S, et al. 2015. Viral Hepatitis in Pregnancy-A study with its effect on Mternal and Foetal Outcome. Journal of the association of physicians of india. 2015 January. Vol 63.Pg. 28-33.

Simbolon, B. 2008. Pendidikan Kesehatan melalui teman sebaya dalam meningkatkan pengetahuan remaja tentang pencegahan kehamilan yang tidak diinginkan (KTD) di SMAN 3 Manna Kabupaten Bengkulu Selatan. Tesis. Program Studi Ilmu Kesehatan Masyarakat Universitas Gajah Mada. 